\title{
Assessment of heavy metal contamination in Kali river, Uttar Pradesh, India
}

\author{
Saurabh Mishra*, Amit Kumar, Shilpa Yadav and M.K. Singhal \\ (Uttarakhand), India \\ *Corresponding author. E-mail: amit.ag109@gmail.com \\ Received: March 14, 2015; Revised received: September 18, 2015; Accepted: December 12, 2015
}

Biomass and Ecosystem lab, Alternate Hydro Energy Centre, Indian Institute of Technology Roorkee- 247667

Abstract: The River Kali is an important surface water body in the western Uttar Pradesh (U.P). It is an intermittent river which flows throughout the monsoonal months. The present study aims to assess the heavy metal contamination in the river Kali using pollution index (PI), based on five heavy metals ( $\mathrm{Fe}, \mathrm{Zn}, \mathrm{Cd}, \mathrm{Pb}$, and $\mathrm{Cr}$ ) during pre and post monsoon seasons in the year 2014. The PI evaluated during pre and post monsoon seasons with respect to drinking water quality standards was found as 5.04 and 7.08 respectively, while related to inland water quality standards were found as 4.37 and 3.62, respectively. The results indicate that the river Kali was severely contaminated $(\mathrm{Pl}>3)$ in both seasons. Therefore, water of Kali River is not fit for drinking as well as for agriculture purposes.

Keywords: Heavy metals, Pollution index, River Kali, Water quality

\section{INTRODUCTION}

River water, a natural source forms the lifeline of all living organisms. Water pollution, which is a major environmental issue in India, is the introduction of contaminating pollutions into the natural water leading to an adverse change. The rapid industrialization near to water bodies and the untreated discharge of industrial effluents like toxic heavy metal contaminant degrade the water quality. Because of their bioaccumulation capacity and environmental persistence, special attention has been paid on toxic trace elements (Alves et al., 2014). These chemicals may enter aquatic compartments through a variety of routes, therefore impairing the quality of not only aquatic ecosystems, but also human health (Bao et al., 2012). As a consequence, multidisciplinary approaches combining chemical, eco -toxicological and ecological data in accordance with the Triad approach have been developed around the world (Benedetti et al., 2012). However, the number of potentially hazardous chemicals is ever growing, rendering a complete chemical characterization of contaminants almost impossible (Vink et al., 1999). The river water quality was being continuously degraded due to the ever increasing disposal of municipal and industrial waste from the nearby region (Jain et al., 1997). Traces of heavy metals such as Pb, Mn, Fe and $\mathrm{Cr}$ have been identified as deleterious to aquatic ecosystems and human health (Panakkal and Kumar, 2014). Although several reports on water quality, planktonic and limnology of river have been published (Bhargava et al., 2009; Sirohi et al., 2014; Kapsikar et al., 2011; Ghosh and Mcbean, 1998; CPCB, 2012), but a comprehensive monitoring of heavy metals in the surface water of river Kali has not been carried out yet. Therefore, in the present study, an attempt has been made to assess the degree of heavy metals contamination in Kali River at seven sampling locations $\left(R_{1}\right.$ to $\mathrm{R}_{7}$ ) at Uttar Pradesh (U.P) to calculate the pollution with respect to (w.r.t) drinking water quality and inland water quality standards so that a suitable conservation plan could be prepared and implemented.

\section{MATERIALS AND METHODS}

Study site: River Kali East is an intermittent river which flows actively; in monsoonal months. It originates from a village called Antwada near Khatauli in Western UP. Kali River is a tributary of the Hindon River which again is a tributary of the Yamuna River, and eventually flows into the Ganga River near district Kannauj in Uttar Pradesh. It originates near Antwada village of district Muzzafarnagar in Uttar Pradesh at coordinate $29^{\circ} 9^{\prime} 34.29^{\prime \prime} \mathrm{N}$ to $27^{\circ} 11^{\prime} 321.34 " \mathrm{~N}$ and $77^{\circ} 45^{\prime}$ $15.10^{\prime \prime} \mathrm{E}$ to $77^{\circ} 58^{\prime} 14.03$ "E. it covers catchment area of $1425.21 \mathrm{~km}^{2}$ and travels a length of $150 \mathrm{~km}$ (approximately) before joining the river Ganga. The climatic condition of the area is characterized as a moderate subtropical monsoon. The major land use surrounding the river is agriculture and there is no forest cover. The soil of this area is silt loamy and free of carbonates. Moreover, during the monsoon period, the Kali River flow increases to a level approx. 10 to 12 times higher than the dry season flow and floods into the over banks in many stretches. The sampling locations have been given in Table 1 and Fig. 1 .

Calculation of contamination index (CI) and pollution index (PI): The CI and PI here have been used to identify the enrichment of heavy metals with respect to 
Table 1. Different surface water sampling locations.

\begin{tabular}{|c|c|c|c|}
\hline S. N. & Sampling location & Coordinates & Code \\
\hline 1 & $\begin{array}{l}\text { Near Gesupur } \\
\text { Village }\end{array}$ & $\begin{array}{l}29^{\circ} 2^{\prime} 9.74 " \mathrm{~N} \text { to } \\
77^{\circ} 47^{\prime} 10.90 " \mathrm{E}\end{array}$ & $\mathrm{R}_{1}$ \\
\hline 2 & $\begin{array}{l}\text { After confluence of } \\
\text { Abu Nala } 1\end{array}$ & $\begin{array}{l}28^{\circ} 57^{\prime} 42.98^{\prime \prime} \mathrm{N} \text { to } \\
77^{\circ} 45^{\prime} 53.47^{\prime \prime} \mathrm{E}\end{array}$ & $\mathrm{R}_{2}$ \\
\hline 3 & $\begin{array}{l}\text { After confluence of } \\
\text { Abu Nala } 2\end{array}$ & $\begin{array}{l}28^{\circ} 57^{\prime} 7.38 " \mathrm{~N} \text { to } \\
77^{\circ} 44^{\prime} 37.81^{\prime \prime} \mathrm{E}\end{array}$ & $\mathrm{R}_{3}$ \\
\hline 4 & $\begin{array}{l}\text { After confluence of } \\
\text { Meerut drain }\end{array}$ & $\begin{array}{l}28^{\circ} 56^{\prime} 29.68^{\prime \prime} \mathrm{N} \text { to } \\
77^{\circ} 44^{\prime} 18.26^{\prime \prime} \mathrm{E}\end{array}$ & $\mathrm{R}_{4}$ \\
\hline 5 & $\begin{array}{l}\text { Near Pipli Khera } \\
\text { village }\end{array}$ & $\begin{array}{l}28^{\circ} 48^{\prime} 42.34 " \mathrm{~N} \mathrm{~N} \\
\text { to } 77^{\circ} 44^{\prime} 18.26^{\prime \prime} \mathrm{E}\end{array}$ & $\mathrm{R}_{5}$ \\
\hline 6 & Near Kaol village & $\begin{array}{l}28^{\circ} 48^{\prime} 42.34^{\prime \prime N} \text { to } \\
77^{\circ} 48^{\prime} 43.63^{\prime \prime} \mathrm{E}\end{array}$ & $\mathrm{R}_{6}$ \\
\hline 7 & Near Ajrara village & $\begin{array}{l}28^{\circ} 47^{\prime} ' 71.41 " \mathrm{~N} \text { to } \\
77^{\circ} 57^{\prime} 43.63^{\prime \prime} \mathrm{E}\end{array}$ & $\mathrm{R}_{7}$ \\
\hline
\end{tabular}

the maximum permissible limit for standard discharge of environmental pollutant to inland water and standard permissible drinking water quality. The pollution index of individual heavy metal was calculated by equation 1 and the contamination index for potentially toxic heavy metal in the river was calculated by equation 2 :

$$
\begin{aligned}
& \mathrm{Pi}=\frac{\text { Measured concentation of individual heavy metal }}{\text { Standard permisible concentration of heavy metal }} \\
& \mathrm{CI}=\frac{1}{5} \sum_{\mathrm{Pi}}
\end{aligned}
$$

Where, $\mathrm{Pi}$ is the pollution index of individual heavy metal; CI is the contamination index. The contamination index is classified as CI $>5$ (contaminated), CI; $1-5$ (slightly contaminated) and $\mathrm{CI}<1$ (not contaminated). Further, to determine the magnitude contribution of individual heavy metal to toxicity of an area, the single factor index, Nemerow pollution index (Yang et al., 2013) is applied for river water quality with respect to heavy metal. The Nemerow pollution index (PI) is widely applied to reflect the total pollution level and evaluate environmental quality. It was calculated by equation 3 :

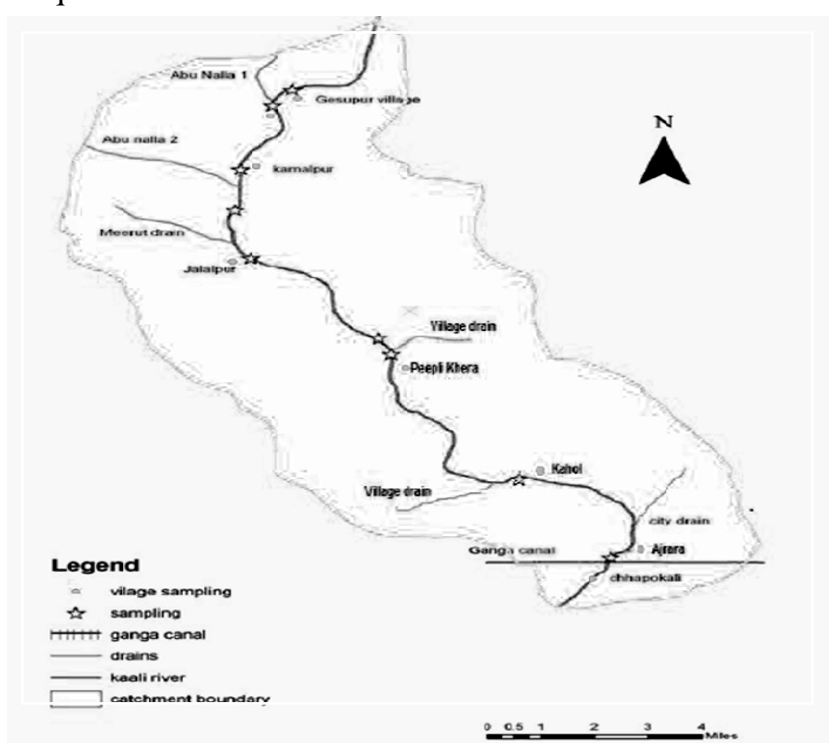

Fig. 1. Schematic diagram of Kali River with specified sampling locations.

$$
P I=\sqrt{\frac{1}{2}\left(P_{\max ^{2}}{ }^{2}+\mathrm{CI}^{2}\right)}
$$

Where, PI is the Nemerow pollution index; $\mathrm{Pi}_{\max }$ is the maximum value of pollution indices of all five heavy metals considered at particular sampling location. The range for which $\mathrm{PI}$ is classified as: $\mathrm{P} \leq 1$ (water not contaminated); $2<\mathrm{P} \leq 3$ (slightly contaminated) and $\mathrm{P}>3$ water severely contaminated. The inland water quality standards and drinking water quality standards of the five heavy metals considered were obtained from the Central Pollution Control Board (CPCB, 2012; EPA 1996) and BIS, 1991 norms of the Indian government for general discharge of environmental pollutant to assess contamination of heavy metals in river Kali.

Data collection and analysis: The data of heavy metal concentration for analysis and calculation of indices were obtained from the laboratory experiment during pre monsoon (March-May) and the post monsoon (OctDec) in the year 2014 at seven sampling locations. Samples from surface water were collected directly by hand in a wide mouth glass jar, while the deep water samples were withdrawn by Vendorn-type water sampler. The water samples were stored at $4^{\circ} \mathrm{C}$ transported to the laboratory within an hour and analyses were done on the same day. The heavy metals were analyzed using HACHSpectrophotometer taking in account the unit of measurement as mg/l (APHA, 2005) and the data obtained during analysis at all sampling locations were converted into the overall mean and standard deviation of each heavy metal concentration for the overall river water quality and is shown in Table 2. The data was converted into individual pollution index $(\mathrm{Pi})$ value using equation 1 . The contamination index $(\mathrm{CI})$ is then calculated by averaging the $\mathrm{Pi}$ value of all five heavy metals at particular sampling location for both pre and post monsoon using equation 2 . Then, Pi value was evaluated using equation 3 .

According to WHO, all the heavy metals were above the permissible limits. The pollution index and contamination index values with respect to the general standard for environmental pollutant discharge for inland water bodies are represented in Table $3 \& 4$ for both pre and post monsoon sampling respectively. While, using a denominator for calculating Pi as drinking water quality standard, CI and PI values are represented in Table 5 and 6 , respectively for both pre and post monsoon.

Slight variation in PI was found at most of the sampling locations in the pre-monsoon to post-monsoon season, but at some of the locations where $\mathrm{PI}>3$, can be due to nutrient enrichment during the rainy season. It was also revealed that the PI was more specific in classifying the contamination level in the water stream than CI (Tables 3-6).

\section{RESULTS AND DISCUSSION}

The Kali river water quality was assessed using the five heavy metal parameter for different sampling locations. The seasonal variation of different heavy metals in water from Kali River is depicted in Table 2. The 
Table 2. Mean value of the data obtained during analysis in river Kali.

\begin{tabular}{|c|c|c|c|c|c|}
\hline \multirow[t]{2}{*}{ S. N. } & \multirow[t]{2}{*}{$\begin{array}{l}\text { Heavy } \\
\text { metals }\end{array}$} & \multicolumn{2}{|c|}{$\begin{array}{c}\text { Water quality in present study } \\
(\text { Mean } \pm \text { S.D) }\end{array}$} & \multirow[t]{2}{*}{$\begin{array}{c}\text { Inland water quality } \\
(\mathrm{mg} / \mathrm{l})\end{array}$} & \multirow[t]{2}{*}{$\begin{array}{c}\text { Drinking water quality } \\
(\mathrm{mg} / \mathrm{l})\end{array}$} \\
\hline & & Pre-monsoon & Post-monsoon & & \\
\hline 1 & $\overline{\mathrm{Fe}}$ & $1.77 \pm 0.87$ & $1.53 \pm 0.75$ & 3 & 0.30 \\
\hline 2 & $\mathrm{Cr}$ & $0.09 \pm 0.03$ & $0.06 \pm 0.02$ & 2 & 0.05 \\
\hline 3 & $\mathrm{Cd}$ & $0.08 \pm 0.03$ & $0.06 \pm 0.03$ & 2 & 0.01 \\
\hline 4 & $\mathrm{Zn}$ & $29.71 \pm 7.59$ & $24.71 \pm 6.42$ & 5 & 5 \\
\hline 5 & $\mathrm{~Pb}$ & $0.19 \pm 0.13$ & $0.13 \pm 0.07$ & 0.10 & 0.10 \\
\hline
\end{tabular}

Table 3. CI and PI w.r.t inland water quality standard during pre-monsoon (March 2014 to May 2014)

\begin{tabular}{cccccccccc}
\hline $\begin{array}{c}\text { Sampling } \\
\text { locations }\end{array}$ & $\mathbf{P i}(\mathbf{F e})$ & $\mathbf{P i}(\mathbf{Z n})$ & $\mathbf{P i}(\mathbf{P b})$ & $\mathbf{P i}(\mathbf{C r})$ & $\begin{array}{c}\mathbf{P i} \\
(\mathbf{C d})\end{array}$ & $\mathbf{C I}$ & $\mathbf{P i}_{\max }$ & $\mathbf{P I}$ & $\begin{array}{c}\text { Water quality } \\
\text { contamination }\end{array}$ \\
\hline $\mathrm{R}_{1}$ & 0.19 & 4.00 & 0.80 & 0.03 & 0.02 & 1.01 & 4.00 & 2.92 & Moderate \\
$\mathrm{R}_{2}$ & 0.31 & 4.80 & 0.90 & 0.04 & 0.04 & 1.22 & 4.80 & 3.50 & Severe \\
$\mathrm{R}_{3}$ & 0.47 & 5.80 & 1.20 & 0.04 & 0.04 & 1.51 & 5.80 & 4.24 & Severe \\
$\mathrm{R}_{4}$ & 0.63 & 5.00 & 0.92 & 0.04 & 0.04 & 1.32 & 5.00 & 3.66 & Severe \\
$\mathrm{R}_{5}$ & 0.68 & 6.40 & 2.40 & 0.05 & 0.05 & 1.91 & 6.40 & 4.72 & Severe \\
$\mathrm{R}_{6}$ & 0.87 & 7.20 & 3.50 & 0.06 & 0.05 & 2.34 & 7.20 & 5.35 & Severe \\
$\mathrm{R}_{7}$ & 0.99 & 8.40 & 3.90 & 0.07 & 0.06 & 2.68 & 8.40 & 6.24 & Severe \\
& & & & & Average & 1.35 & - & 3.62 & Severe \\
\hline
\end{tabular}

Table 4. The CI and PI w.r.t inland water quality standard during post-monsoon (October 2014 to December 2014).

\begin{tabular}{cccccccccc}
\hline $\begin{array}{c}\text { Sampling } \\
\text { locations }\end{array}$ & $\begin{array}{c}\mathbf{P i} \\
(\mathbf{F e})\end{array}$ & $\begin{array}{c}\mathbf{P i} \\
(\mathbf{Z n})\end{array}$ & $\mathbf{P i}(\mathbf{P b})$ & $\mathbf{P i}(\mathbf{C r})$ & $\begin{array}{c}\mathbf{P i} \\
(\mathbf{C d})\end{array}$ & $\mathbf{C I}$ & $\mathbf{P i}_{\text {max }}$ & $\mathbf{P I}$ & $\begin{array}{c}\text { Water quality } \\
\text { contamination }\end{array}$ \\
\hline $\mathrm{R}_{1}$ & 0.17 & 3.20 & 0.50 & 0.02 & 0.01 & 0.78 & 3.20 & 2.33 & Moderate \\
$\mathrm{R}_{2}$ & 0.29 & 3.80 & 0.70 & 0.02 & 0.02 & 0.96 & 3.80 & 2.77 & Moderate \\
$\mathrm{R}_{3}$ & 0.40 & 5.00 & 0.98 & 0.03 & 0.03 & 1.29 & 5.00 & 3.65 & Severe \\
$\mathrm{R}_{4}$ & 0.47 & 4.20 & 0.72 & 0.03 & 0.03 & 1.09 & 4.20 & 3.07 & Severe \\
$\mathrm{R}_{5}$ & 0.63 & 5.60 & 1.60 & 0.04 & 0.04 & 1.58 & 5.60 & 4.11 & Severe \\
$\mathrm{R}_{6}$ & 0.74 & 6.00 & 2.00 & 0.04 & 0.04 & 1.76 & 6.00 & 4.42 & Severe \\
$\mathrm{R}_{7}$ & 0.87 & 6.80 & 2.30 & 0.05 & 0.05 & 2.01 & 6.80 & 5.01 & Severe \\
& & & & & Average & 1.35 & - & 3.62 & Severe \\
\hline
\end{tabular}

laboratory analysis of samples indicates that the river was supplemented with heavy load of $\mathrm{Zn}$ and $\mathrm{Pb}$, which were found to be very high than the standard limit of inland water quality that led the river water unfit for agricultural use. While all five heavy metals concentrations were found higher than standard permissible limit of drinking water quality therefore river water was unsuitable for drinking purpose. Further, in order to classify the laboratory findings comprehensively, the PI and CI were calculated with respect to inland water quality standard during pre and post monsoon as represented in Table 3 and 4, respectively. The result showed that the $\mathrm{CI}$ was in the range of $1-5$ in both the season, was an indication of slightly contaminated water quality at most of sampling locations, except $R_{1}$ and $R_{2}$. Moreover, the PI was found in the range PI $>3$ at most of sampling locations indicating the severely contaminated water quality, except at $\mathrm{R}_{1}$ $(\mathrm{PI}<3)$ was an indication of moderately contaminated, during both the seasons, while at $\mathrm{R}_{2}$, the PI was found as 2.77 during post-monsoon and 3.50 during the premonsoon season. Based on the results obtained, it has been revealed that the water quality of river kali is not suitable for agricultural purpose. Furthermore, the CI and PI with respect to drinking water quality standard of heavy metals is evaluated and shown in Tables 5 and 6 for pre and post monsoon, respectively. The CI was found in the range 1-5 whereas PI was in range PI $>3$ in both the seasons at all sampling locations except $\mathrm{R}_{1}$ (Tables 4 and 6). The variation in CI was also found in pre monsoon (PI>3) and post monsoon (PI, 2-3), is due to dilution of river water.

The present study indicated that the accumulated concentration of heavy metals in the Kali River is minimum during post-monsoon and maximum during premonsoon. Reason behind, after rainy season (JulyAugust), rivers is highly flooded and the drainage system is drastically affected, which results in mixing of polluted and unpolluted water. This leads to decrease in heavy metal concentration, whereas increase in the concentration of metals during pre-monsoon might be due to drought and reduction in water levels. From the above it was found that the overall PI is $4.79 \& 3.73$ in pre monsoon and post monsoon respectively which shows that water is severely contaminated and is not suitable for drinking and other life supporting activities. The present findings also support the previous studies (Bhargava et al., 2009; Sharma et al., 2014). Bhargava et al. 2009 had studied quality of water on the river Kali using microbial count and had reported 
Table 5. CI and PI w.r.t drinking water quality standard during pre-monsoon (March 2014 to May 2014).

\begin{tabular}{cccccccccc}
\hline $\begin{array}{c}\text { Sampling } \\
\text { locations }\end{array}$ & $\mathbf{P i}(\mathbf{F e})$ & $\begin{array}{c}\mathbf{P i} \\
(\mathbf{Z n})\end{array}$ & $\mathbf{P i}(\mathbf{P b})$ & $\mathbf{P i}(\mathbf{C r})$ & $\mathbf{P i}(\mathbf{C d})$ & $\mathbf{C I}$ & $\mathbf{P i}_{\text {max }}$ & $\mathbf{P I}$ & $\begin{array}{c}\text { Water quality } \\
\text { contamination }\end{array}$ \\
\hline $\mathbf{R}_{\mathbf{1}}$ & 1.87 & 4.00 & 0.80 & 1.36 & 4.00 & 2.41 & 4.00 & 3.30 & Severe \\
$\mathbf{R}_{\mathbf{2}}$ & 3.07 & 4.80 & 0.90 & 1.48 & 7.20 & 3.49 & 4.80 & 4.20 & Severe \\
$\mathbf{R}_{\mathbf{3}}$ & 4.73 & 5.80 & 1.20 & 1.68 & 8.10 & 4.30 & 5.80 & 5.11 & Severe \\
$\mathbf{R}_{\mathbf{4}}$ & 6.27 & 5.00 & 0.92 & 1.54 & 7.30 & 4.21 & 5.00 & 4.62 & Severe \\
$\mathbf{R}_{\mathbf{5}}$ & 6.77 & 6.40 & 2.40 & 1.84 & 9.50 & 5.38 & 6.40 & 5.91 & Severe \\
$\mathbf{R}_{\mathbf{6}}$ & 8.70 & 7.20 & 3.50 & 2.20 & 10.00 & 6.32 & 7.20 & 6.77 & Severe \\
$\mathbf{R}_{\mathbf{7}}$ & 9.87 & 8.40 & 3.90 & 2.80 & 12.00 & 7.39 & 8.40 & 7.91 & Severe \\
& & & & & Average & 4.79 & & 5.40 & Severe \\
\hline
\end{tabular}

Table 6. CI and PI w.r.t drinking water quality standard during post-monsoon (October 2014 to December 2014).

\begin{tabular}{cccccccccc}
\hline $\begin{array}{l}\text { Sampling } \\
\text { locations }\end{array}$ & $\mathbf{P i}(\mathbf{F e})$ & $\begin{array}{c}\mathbf{P i} \\
(\mathbf{Z n})\end{array}$ & $\mathbf{P i}(\mathbf{P b})$ & $\mathbf{P i}(\mathbf{C r})$ & $\begin{array}{c}\mathbf{P i} \\
(\mathbf{C d})\end{array}$ & $\mathbf{C I}$ & $\mathbf{P i}_{\text {max }}$ & $\mathbf{P I}$ & $\begin{array}{c}\text { Water quality } \\
\text { contamination }\end{array}$ \\
\hline $\mathbf{R}_{\mathbf{1}}$ & 1.67 & 3.20 & 0.50 & 0.64 & 2.50 & 1.70 & 3.20 & 2.56 & Moderate \\
$\mathbf{R}_{\mathbf{2}}$ & 2.87 & 3.80 & 0.70 & 0.84 & 3.20 & 2.28 & 3.80 & 3.13 & Severe \\
$\mathbf{R}_{\mathbf{3}}$ & 4.00 & 5.00 & 0.98 & 1.22 & 6.10 & 3.46 & 6.10 & 4.96 & Severe \\
$\mathbf{R}_{\mathbf{4}}$ & 4.67 & 4.20 & 0.72 & 1.16 & 5.40 & 3.23 & 5.40 & 4.45 & Severe \\
$\mathbf{R}_{\mathbf{5}}$ & 6.33 & 5.60 & 1.60 & 1.50 & 7.20 & 4.45 & 7.20 & 5.98 & Severe \\
$\mathbf{R}_{\mathbf{6}}$ & 7.40 & 6.00 & 2.00 & 1.64 & 8.60 & 5.13 & 8.60 & 7.08 & Severe \\
$\mathbf{R}_{\mathbf{7}}$ & 8.67 & 6.80 & 2.30 & 1.90 & 9.60 & 5.85 & 9.60 & 7.95 & Severe \\
& & & & & Average & 3.73 & & 5.16 & Severe \\
\hline
\end{tabular}

that the most probable number (MPN) of coliform are in the range of 38.6-43.3 MPN/100 ml whereas planktons were in range of 749-900 in year 2008-09, which is in line with and supports the observations derived in present study. Further, Sharma et al. (2014) also studied the same using physico-chemical parameters and found the same status as provided in our present study. Therefore, to bring an improvement in the river water quality, corrective conservation measures may be appropriately taken by concerned authorities so that river pollution might be reduced in the future and river may regain its historical importance.

\section{Conclusion}

Based on the analysis of heavy metals, it has been revealed that $\mathrm{Zn}$ and $\mathrm{Pb}$ are the major parameters responsible for water pollution in the river Kali. The overall PI indicates that, the river water was severely contaminated (i.e. PI>3) in both seasons with respect to both standard for inland water quality and drinking water quality. This severe contamination was mainly due to land run off, dredging, other linked anthropogenic activities and the discharge of industrial/urban effluents into river Kali. To classify the contamination level, PI was more significant to CI. The PI variation in both pre and post monsoon season indicated that the river was more contaminated during pre monsoon than the post monsoon. This variation may be due to the addition of waste water during rainy season. The result also revealed that river water is not fit for irrigation as well as drinking purposes.

\section{ACKNOWLEDGEMENTS}

One of the authors (SM \& SY) is thankful to MHRD, Government of India for financial assistance in the form of scholarship during his M.Tech in Environmental Management of Rivers and Lakes, IIT Roorkee. Authors are highly thankful to the reviewer to improve the quality of the paper.

\section{REFERENCES}

Alves, R.S. Sampaio, C.F. Nadal, M. Schuhmacher, M. Domingo, J.L. and Munoz, S.S. (2014). Metal Concentrations in Surface Water and Sediments from Pardo River, Brazil: Human health risks. Environ. Res., 133:149-155.

APHA (2005). Standard Methods for Examination of Water and Waste Water. American Public Health Association, NewYork, U. S.A.

Bao, L.J. Maruya, K.A. Snyder, S.A. and Zeng, E.Y. (2012). China's Water Pollution by Persistent Organic Pollutants. Environ. Pollut., 163, 100-108.

Benedetti, M. Ciaprini, F. Piva, F. Onorati, F. Fattorini, D. and Notti, A. (2012). A Multidisciplinary Weight of Evidence Approach for Classifying Polluted Sediments: Integrating Sediment Chemistry, Bioavailability, Biomarkers Responses and Bioassays. Environ. Int., 38: 17 -28 .

Bhargava, S. Saxena, U. and Bhragava, A.K. (2009). Some Microbiological Studies of Polluted Kali river water at Meerut. Biochem. Cell, Arch., 9: 155-156.

BIS (1991). Indian Standard Specification for Drinking Water, Bureau of Indian Standards. BIS: 10500.

CPCB (2012). Reconnaissance Survey of Pollution Load of River Kali, Central Pollution Control Board, Ministry of Environment and Forests, New Delhi.

EPA (1996). General Standards for Discharge of Environmental Pollutants. Environment (Protection) Amendment Rules, Notified by G.S.R. 176.

Ghosh, N.C. and Mcbean, E.A. (1998). Water Quality Modeling of the Kali River, India. Water, Air, Soil Pol., 102: 91-103.

Jain, C.K. Bhatia, K.K.S. and Seth, S.M. (1997). Assessment of Point and Non-Point Sources of Pollution Using a 
Chemical Mass Balance Approach. Hydrol. Sci. J., 43: 379-390.

Kapsikar, G.B. Khajure, P.V. and Rathod, J.L. (2011). Physico-Chemical Features of Kali River, Karwar, West Coast of India. Recent Res. Sci. Tech., 3: 12-14.

Panakkal, A. and Kumar, B. (2014). Evaluation of the Trace Metal Contamination in Sediments of the Urban Water Channels in Thrissur City, South India. Nat. Environ. Poll. Tech. 13: 701-706.

Sharma, M.K. Jain, C.K. and Singh, O. (2014) Characterization of point sources and water quality assessment of River Hindon using water quality index. J. Indi. Water Res. Soc., 34:53-64.
Sirohi, S. Sirohi, S.P.S. and Tyagi, P.K. (2014). Impact of industrial effluents on water quality of Kali River in different locations of Meerut, India. J. Engg. Tech. Res., 6: 4347.

Vink, R. Behrendt H. and Salomons W. (1999). Development of the Heavy Metal Pollution Trends in Several European Rivers: An Analysis of Point and Diffuse Sources. Water Sci. Technol., 39: 215-23.

Yang, C.L. Guo, R.P. Yue, Q.L. Zhou, K. and Wu, Z.F. (2013). Environmental Quality Assess-Ment and Spatial Pattern of Potentially Toxic Elements in Soils of Guangdong Province, China. Environ. Earth Sci., 70: 1903-1910. 